\title{
304 レーザ反射法によるマイクロ発電風車翼の変形計測 Measurement of blade deformation of a micro wind turbine by the laser reflection method
}

\author{
○小野里 学（千葉大）佐藤 理人（千葉大）正 佐藤 建吉（千葉大）
}

Manabu ONOZATO, Graduate School of Chiba University, 1-33 Yayoi-cho, Inage-ku, Chiba

\begin{abstract}
The application of wind power generations has been markedly increased in Japan. However, acoustic noise generated from turbine blades is a problem having high-speed-rotation-type micro wind turbines. In order to study the acoustic noise, the deformation of blades under rotation has been measured using the laser reflection method. Two types of blade of micro wind turbines, AIR 303 and AIR 403, were tested. The FFT analysis of the noise has been carried out. It has been clarified that the twist deformation of the blade is related to acoustic noise generation.
\end{abstract}

Key Words: Wind Turbine, Acoustic Noise, Deformation of Blade, Laser Technique, FFT

\section{1. 緒言}

近年マイクロ発電風車は技術の向上、環境意識の高まりな どの理由から需要が高まっている。しかし設置される場所が 大型発電風車と違い、ビルの屋上や一般家屋といった人の生 活圈内に存在することが多いため、強風時に発生する騒音が 問題とされている。そこで本研究ではマイクロ風車の騒音の 原因を明らかにし、低騒音の風車および翼とするため、騒音 と密接に関係する回転中の翼の変形を、レーザ反射法により 計測した。またそれと同時に騒音の周波数分析も行った。 2. 供試風車

本研究で使用したマイクロ発電風車は、国内での販売台数 が多い AIR303 と AIR403(Southwest Windpower 社、水平軸ア ップウィンド型 3 枚翼)である。供試風車の仕様は Table1に 示す。

Table 1 Specification of AIR303 and AIR403.

\begin{tabular}{c|c|c}
\hline & AIR303 & AIR403 \\
\hline \hline Blade diameter (m) & 1.14 & 1.15 \\
\hline Blade mass (g) & 184 & 195 \\
\hline Cut-in speed (m/s) & 2.2 & 2.7 \\
\hline Rated power (W) & 300 & 400 \\
\hline Peak power (W) & 400 & 600 \\
\hline Attack angle of the tip ( ${ }^{\circ}$ ) & 0.1 & 2.8 \\
\hline
\end{tabular}

\section{3. 実験方法}

3.1 レーザ反射法

翼の変形は、翼にひずみゲージを貼り、ひずみ值から求め ることができるが、マイクロ発電風車は翼弦長が $0.6 \mathrm{~m}$ と小 型であるため、翼の表面のひずみゲージやそれに伴うリード 線などは、翼の形状を変えてしまい、それによって新たな振 動や騒音を誘起するのでマイクロ発電風車には適さない。 そこで本研究ではレーザ反射法で翼変形計測を行った。レ 一ザ反射法の原理を Fig.1 に示す。回転している翼にレーザ を回転面に対し垂直に照射し、方眼目盛の刻まれたスクリー ン上に反射させる。この反射されたレーザスポットの $\mathrm{x} 、 \mathrm{y}$ 方向変位 $\Delta \mathrm{x} 、 \Delta \mathrm{y}$ からたわみ角 $\alpha$ とねじれ角 $\beta$ の変化を計測 するという方法である。式(1)、(2)よりたわみ角 $\alpha$ とねじれ 角 $\beta$ が算出できる。また 3 枚の翼のうち 1 枚だけにレーザを 反射させる薄いプラスチックフィルムを貼り、1枚の翼に限 定して計測できるようにした。

\section{2 翼の変形計測}

実験装置を Fig.2 に示す。翼を一定に回転させるために屋 内にてモー夕(TOSHIBA 社製, IK-FCKK8，2P-0.75kW)を使 用し、回転させた。赤色レーザ照射装置は NEC 社製 GLG5260

（He-Ne Laser, Max10mW）を使用した。計測時間は 10 秒間 で、測定した回転速度は 300rpm から 2400rpm まで 300rpm
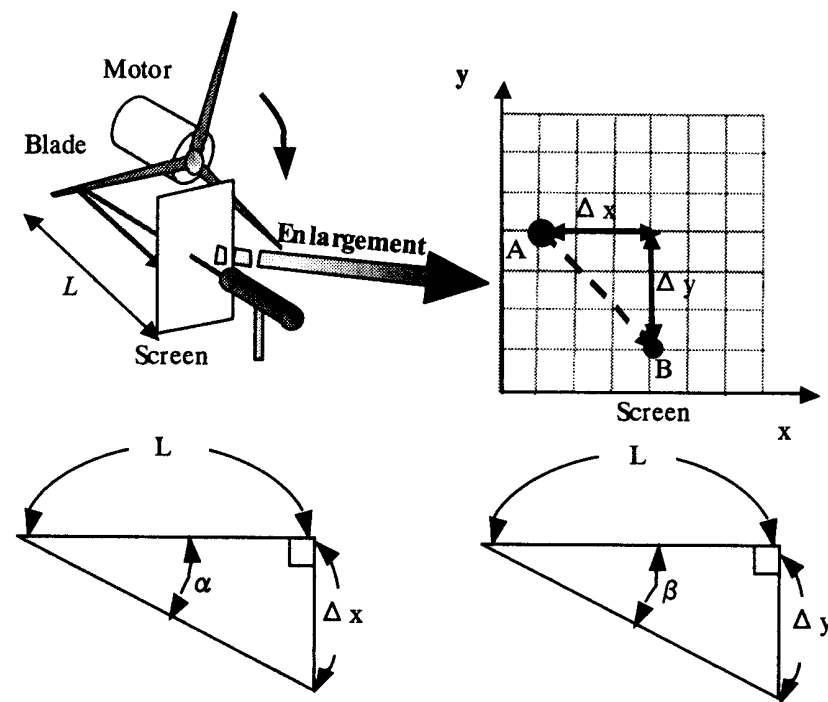

$$
\begin{aligned}
& \text { - Bend angle } \alpha=\tan ^{-1}(\Delta \mathrm{x} / \mathrm{L}) \\
& \text { - Twist angle } \beta=\tan ^{-1}(\Delta \mathrm{y} / \mathrm{L})
\end{aligned}
$$

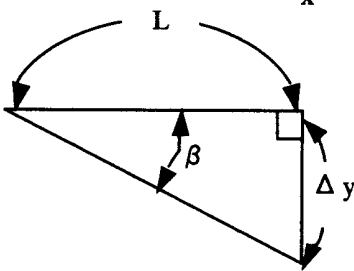

A: Reflected position of before rotation $\Delta \mathrm{x}$ : Deviat ion of $\mathrm{x}$-direction B: Reflected position of after rotation $\Delta y$ : Deviation of $y$-direction $L$ : Distance between blade and screen

Fig.1 The principle of the laser reflection method.

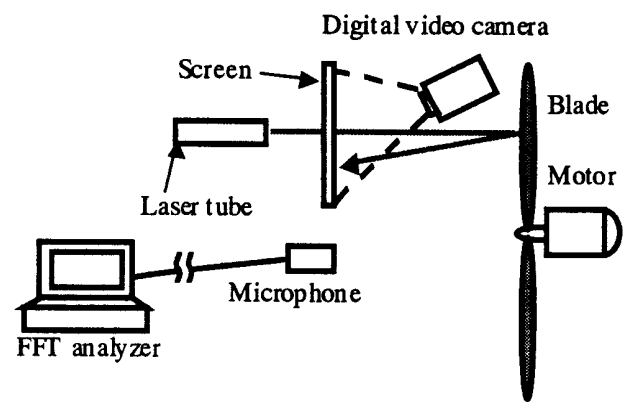

Fig.2 Experimental apparatus.

間隔で行ったが、AIR303 の翼はモー夕に負荷が大きいため 2100rpm までしか計測が行えなかった。翼の変形は先端から $15 \mathrm{~mm}$ の位置にレーザを照射し、またその反射光のスポット をデジタルビデオカメラにより撮影して計測した。

3.3 騒音の周波数分析

騒音の評価や対策を行うために FFT アナライザを用いて 周波数分析を行った。測定は風車前方距離 $1 \mathrm{~m}$ の位置にマイ クロホンを設置して行った。 


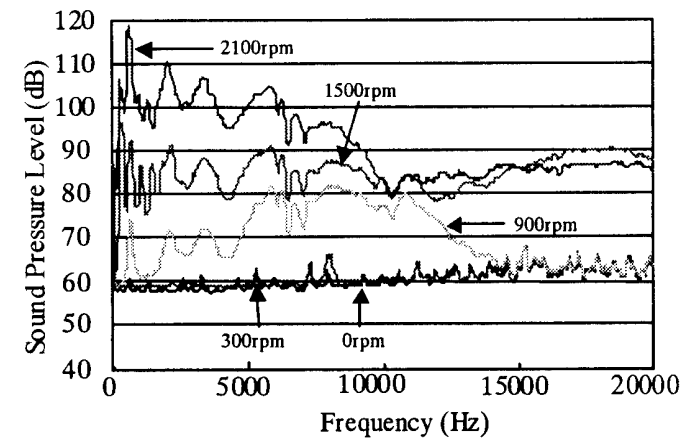

(a) AIR303

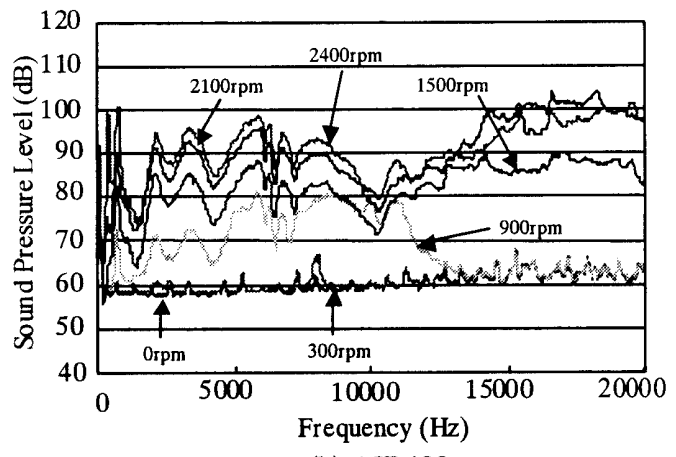

(b) AIR403

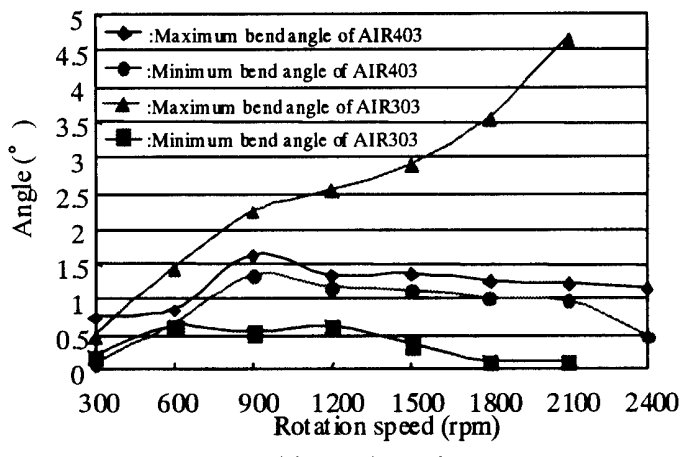

(a) Bend Angle

Fig. 3 Analy sis of Frequency.

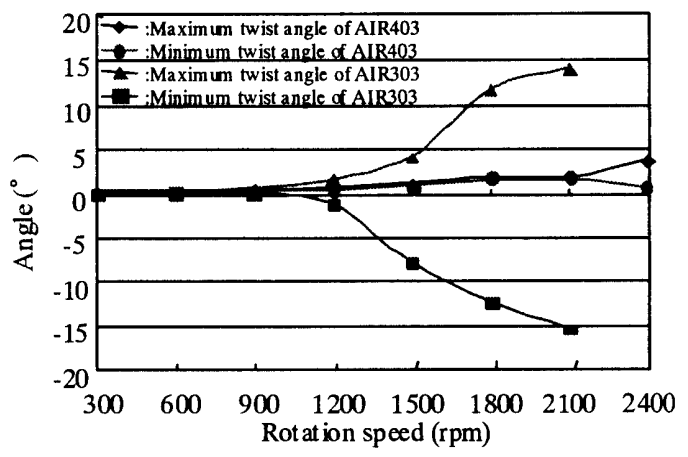

(b) Twist Angle

Fig 4 Change of maximum and minimum angles with rotation speed.

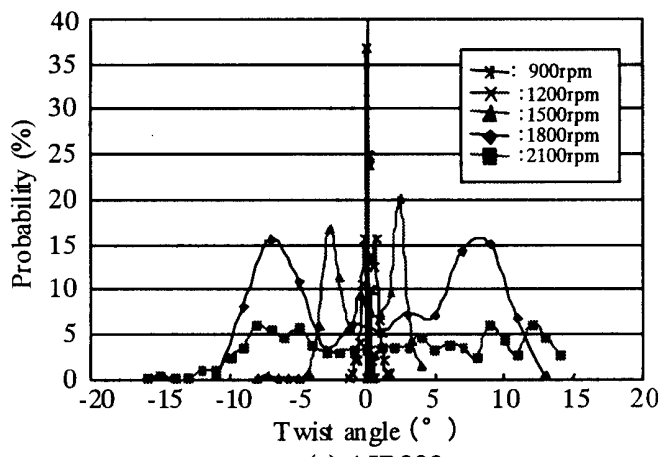

(a) AIR303

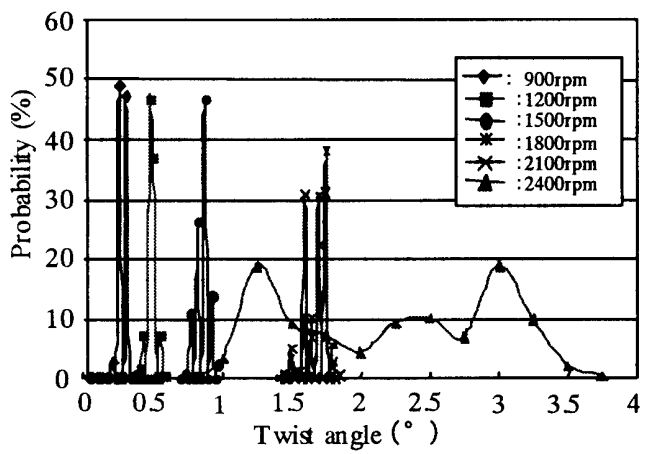

(b) AIR403

Fig.5 Change of twist angle distributions with rotation speed.

\section{4. 実験結果と考察}

AIR303 翼と AIR403 翼の騒音計測結果をそれぞれ Fig.3の (a)、(b)に示す。回転速度が上がるとともに Air303 は $10^{4} \mathrm{~Hz}$ 以下の周波数域の上昇が大きく、その騒音は離散的になって いる。それに対し AIR403 翼は $10^{4} \mathrm{~Hz}$ 以上の高周波数域が大 きくなり広帯域騒音が発生するという傾向が得られた。音圧 レベルは AIR303 では 2100rpm で約 $120 \mathrm{~dB}$ と大変大きな騒音 が生じているが、Air403 の場合 $2400 \mathrm{rpm}$ においても $100 \mathrm{~dB}$ ほどである。このことから AIR403 は AIR303 に比べ騒音が 低減されていると言える。

Fig.4の(a)、(b)に AIR303 とAIR403の翼のたわみ角 $\alpha$ とね じれ角 $\beta$ の変化を示した。AIR303 は AIR403に比べ、たわみ 角 $\alpha$ およびねじれ角 $\beta$ の変化が大きいことがわかる。特にね じれ角 $\beta$ の変化の違いは著しい。そこでねじれ角に注目し、 Fig.5 の(a)、(b)に実験で得られたねじれ角 $\beta$ のデータをヒス トグラムで表した。データの幅が大きくなるほど変形量は大 きいことになる。AIR303 は 1200rpm からねじれ変形が増大 するのに対し、AIR403 は 2400rpm でようやく現れた。その 他の特徵として、AIR303 はねじれ角がマイナス側にも生じ ていることが挙げられる。これは圧力面（進行方向からの風 圧を受ける面）が入れ代わっていることを意味する。し
かし AIR403 はプラス側にしかねじれないので、圧力面はつ ねに同じということになる。AIR303 は圧力面が入れ代わる ことで翼が不安定になり、低速でもねじれ変形が生じやすい と考えられる。これより翼の迎角が大きく影響していること が示唆される。次に Fig.3の(b)のグラフに注目すると $10^{4} \mathrm{~Hz}$ 以下の周波数域では $2400 \mathrm{rpm}$ の周波数分布は $2100 \mathrm{rpm}$ に比べ 大きくなるが、 $10^{4} \mathrm{~Hz}$ 以上の周波数域になるとそれが逆転す る。Air403において 2100rpm と 2400rpm の大きな違いは、ね じれ変形である。このことから $10^{4} \mathrm{~Hz}$ 以下の周波数域の騒音 は、ねじれ変形が大きく影響していると言える。 5. 結言

(1) レーザ反射法は、 $2000 \mathrm{rpm}$ 以上の高速回転においても 翼変形計測に有効である。

(2) Air403 翼はねじれ変形を小さく抑さえ, 騒音の発生を軽 減させていることがわかった。

（3）ねじれ変形は $10^{4} \mathrm{~Hz}$ 以下の離散周波数騒音に大きく影響 していることが考えられる。

6. 参考文献

(1) 林秀千人, ほか 3 名: 機論, Voi.61-586,(1995)pp.2109-2114.

(2) 深野徹, ほか 3 名: 機論, Vol.51-469(1985)pp.2828-2837. 